\title{
Pemetaan Distribusi Ekosistem Mangrove di Wilayah Kota Surabaya dan Sidoarjo Memanfaatkan Citra Landsat TM-5

\author{
Distribution Mapping of Mangrove Ecosystem in Surabaya and Sidoarjo \\ by Using Landsat TM-5 Imagery
}

\section{Zainul Hidayah}

Jurusan Ilmu Kelautan Universitas Trunojoyo Madura Kampus UTM Jl.Raya Telang No.02 Kamal Bangkalan Madura E-mail : zain.hidayah99@gmail.com

\begin{abstract}
Rapid developments on the coastal regions have become a major thread to mangrove ecosystems. The conversion of mangrove forest into fish ponds, housing and industrial sites make the area of this unique tropical ecosystem decline significantly in the last decade. To prevent further destruction of mangrove ecosystems due to human activities, conservation programs are needed. Therefore, information on mangrove's area as well as their distribution is needed. The main objective of this research was to demonstrate the ability of remote sensing and geographic information technology to provide reliable and accurate data on mangrove forest in Surabaya and Sidoarjo regions. A Landsat TM-5 imagery (acquisition date June $4^{\text {th }}, 2009$ ) data was utilized to produce the map. The results showed that in the 2009 period the area of mangrove forest in Surabaya and Sidoarjo was 378.19 Ha and 1236.42 Ha respectively. However, over $73.5 \%$ area of mangrove in Surabaya and $43.25 \%$ in Surabaya were under critical conditions. Anthropogenic factors and human influence were some of the main factors that cause the condition. Activities such as illegal and uncontrolled logging, conversion of mangrove's area and the lack of people's awareness in the importance of mangrove ecosystems were also problems that lead to the massive damage of mangrove forests.
\end{abstract}

Keywords : mangrove ecosystems, remote sensing, geographic information technology, Surabaya, Sidoarjo

\section{Pendahuluan}

Ekosistem laut merupakan suatu kumpulan integral dari berbagai komponen abiotik (fisikakimia) dan biotik (organisme hidup) yang berkaitan satu sama lain dan saling berinteraksi membentuk suatu unit fungsional (Romimohtarto dan Juwana, 2001). Komponen-komponen ini secara fungsional tidak dapat dipisahkan satu sama lain. Apabila terjadi perubahan pada salah satu dari komponen-komponen tersebut maka, akan menyebabkan perubahan pada komponen lainnya. Perubahan ini tentunya dapat mempengaruhi keseluruhan sistem yang ada, baik dalam kesatuan struktur fungsional maupun dalam keseimbangannya (Nybakken, 1992).

Dewasa ini, perhatian terhadap biota laut semakin meningkat dengan munculnya kesadaran dan minat setiap lapisan masyarakat akan pentingnya lautan. Menurut Bengen (2001) laut sebagai penyedia sumber daya alam yang produktif baik sebagai sumber pangan, tambang mineral, dan energi, media komunikasi maupun kawasan pariwisata. Karena itu wilayah pesisir dan lautan merupakan tumpuan harapan manusia dalam pemenuhan kebutuhan dimasa datang (Dahuri et,al, 2001).

Hutan mangrove seringkali juga disebut hutan pantai, hutan pasang surut, hutan payau atau hutan bakau merupakan tipe hutan tropis yang khas tumbuh disepanjang pantai atau muara sungai dipengaruhi oleh pasang surut air laut (Levinton, 2005). Sebagai salah satu ekosistem pesisir, hutan mangrove Indonesia memiliki keanekaragaman jenis pohon, antara lain: bakau (Rhizopora spp), api-api (Avicennia spp), pedada (Sonneratia spp) dan masih banyak lagi (Bengen, 2001). Hutan mangrove, merupakan salah satu sumber daya alam yang mempunyai nilai dan arti yang sangat penting baik dari segi fisik, biologi maupun sosial ekonomi. Akibat meningkatnya kebutuhan hidup, manusia telah mengintervensi ekosistem tersebut. Hal ini dapat terlihat dari adanya alih fungsi lahan mangrove menjadi tambak, permukiman, areal industri dan sebagainya. Selain itu manusia juga telah melakukan penebangan hutan mangrove yang mengakibatkan kerusakan dari ekosistem mangrove tersebut. Apabila keberadaan kawasan mangrove tidak dapat dipertahankan lagi, maka abrasi pantai tidak dapat dielakkan lagi, pencemaran dari sungai ke laut akan meningkat karena tidak adanya filter polutan, dan zona budidaya aquaculture pun akan terancam dengan sendirinya (Dahuri, 2003). Selain itu, akibat berkurang dan rusaknya ekosistem mangrove adalah hilangnya berbagai spesies ikan dan fauna yang berasosiasi dengan ekosistem mangrove, yang dalam jangka panjang akan mengganggu keseimbangan ekosistem mangrove khususnya dan ekosistem pesisir umumnya. 
Seiring dengan terus berkembangnya penggunaan lahan dan perubahan tutupan lahan yang dilakukan oleh sebagian manusia yang relatif cepat dalam suatu wilayah yang mengalami pengembangan, sehingga diperlukan pemetaan wilayah ini secara kontinyu (Noor dan Suryadiputra, 2006). Metode konvensional seperti pengukuran langsung dilapangan (survay terestris) tidak bisa mencakup daerah yang luas dan juga membutuhkan lebih banyak waktu. Dengan perkembangan teknologi informasi, kebutuhan akan data dan informasi yang cepat dan akurat serta mencakup wilayah yang cukup luas menjadi sangat penting (Hidayah, 2009). Teknologi penginderaan jauh (data spatial berbasis citra satelit) menjadi alternatif yang dapat mendukung penyediaan kebutuhan data spasial. Ekosistem mangrove adalah salah satu obyek yang bisa di indentifikasi dengan menggunakan teknologi penginderaan jauh. Moloney (2007) menjelaskan bahwa letak geografi ekosistem mangrove yang berada pada daerah peralihan darat dan laut memberikan efek perekaman yang khas jika dibandingkan obyek vegetasi darat lainnya . Dari gambaran tersebut diatas jelas adanya beberapa kondisi yang mendesak untuk melakukan pengkajian pemetaan sebaran dan kerapatan hutan mangrove menggunakan data penginderaan jauh.

Pembangunan wilayah pesisir di Jawa Timur, khususnya di kawasan Surabaya dan Siodoarjo saat ini menghadapi permasalahan dasar, yaitu: alih fungsi lahan mangrove menjadi area tambak, permukiman, area industri. Selain itu, perencanaan wilayah pesisir yang belum didasari oleh informasi tentang tingkat kondisi ekosistem wilayah pesisir yang akurat. Tentu saja kondisi ini akan mempersulit upaya pencegahan kerusakan dan konservasi ekosistem mangrove. Oleh sebab itu, data-data kondisi terkini yang tersusun dalam sebuah data base spasial sangat penting keberadaannya untuk mendukung upaya perlindungan ekosistem mangrove. Penelitian ini bertujuan untuk memberikan gambaran tentang kegunaan aplikasi teknologi Sistem Informasi Geografis (SIG) dan penginderaan jauh sebagai salah satu alternatif metode dalam memetakan kondisi serta distribusi ekosistem mangrove, khususnya di kawasan pesisir Surabaya dan Siodoarjo.

\section{Metodologi Penelitian}

Citra yang digunakan dalam penelitian ini adalah citra satelit Landsat TM-5 Akuisisi tanggal 4 Juni 2009. Selain itu, untuk pembuatan peta digital, digunakan pula peta RBI (Rupa Bumi Indonesia) produksi Bakosurtanal skala 1:25.000 sebagai peta dasar. Software yang digunakan dalam pengolahan citra adalah Earth Resources Mapping (ErMapper) ver.7 serta ArcGIS ver.9.2 untuk pembuatan data base spasial dan peta.

Pengolahan citra satelit dimulai dengan tahapan pra processing. Pada tahapan ini terdiri dari dua tahapan : koreksi radiometri dan koreksi geometri. Koreksi radiometri bertujuan untuk memperbaiki kualitas visual citra dan sekaligus memperbaiki nilai-nilai pixel yang tidak sesuai. Koreksi geometri bertujuan untuk meletakkan posisi obyek di citra sesuai dengan posisi sebenarnya di lapangan. Selanjutnya adalah Penajaman citra, dilakukan dengan melakukan komposit pada citra sehingga didapatkan kenampakan citra secara visual lebih jelas. Dengan kenampakan citra yang jelas akan mudah dibedakan antara satu obyek dengan obyek lain, sehingga mudah untuk membuat area sampling (ROI) yang akan dipergunakan dalam klasifikasi tutupan lahan. Komposit yang dipergunakan adalah 453, karena komposit ini lebih menonjolkan obyek sebaran dan kerapatan hutan mangrove (Hidayah dan Muhsoni, 2009).

Tahapan berikutnya adalah klasifikasi tutupan lahan untuk mendapatkan peta tutupan lahan. Metode yang dipergunakan adalah klasifikasi terselia (supervise) dengan metode Maximum Likelihood. Metode ini membutuhkan area sampling (Region of Interest) yang didapatkan dari sampling lapang. Dalam penyusunan klasifikasi menggunakan informasi nilai statistik berupa rerata dan simpangan baku tiap sampel, serta variasi (ragam) dan kovariansi. Setelah didapatkan peta sebaran mangrove kemudian pada area ini dilakukan analisis indeks vegetasi. Metode indeks vegetasi yang dipergunakan adalah NDVI (Normalized Difference Vegetation Index), dengan formula sebagai berikut :

$N D V I=\frac{\text { Saluran Inframerah Dekat }- \text { Saluran Merah }}{\text { Saluran Inframerah Dekat }+ \text { Saluran Merah }}$ 
Secara ringkas, alur analisa citra satelit disajikan dibawah ini.

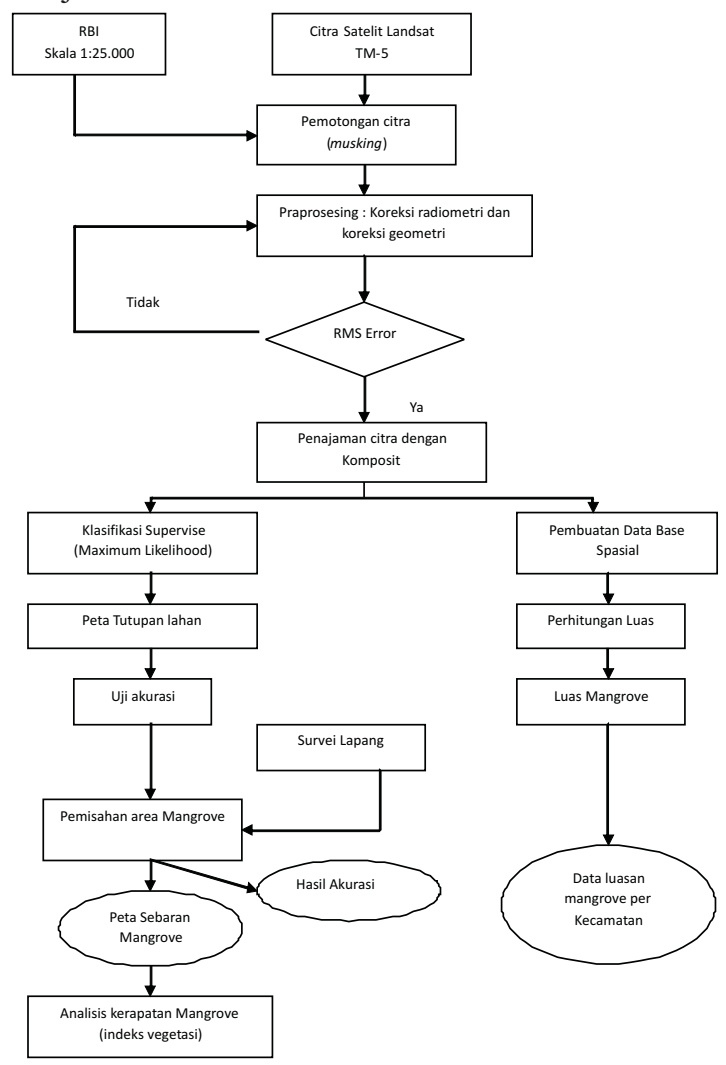

\section{Hasil dan Pembahasan}

Kondisi Ekosistem Mangrove Kota Surabaya

Ekosistem hutan mangrove di wilayah kota Surabaya banyak tersebar di beberapa lokasi pesisir, antara lain : Gununganyar, Rungkut, Sukolilo, Mulyorejo. Selain itu, ekosistem ini juga terdapat di Benowo dan Kenjeran meskipun luasannya relatif sedikit. Gambar peta dibawah ini menjelaskan mengenai lokasi wilayah pesisir yang tersebar di Kota Surabaya dan ditumbuhi oleh ekosistem mangrove. Komposit atau kombinasi saluran/ band yang digunakan untuk menghasilkan citra diatas adalah RGB 453. Kombinasi tersebut umum digunakan untuk membedakan kenampakan vegetasi dengan obyek lainnya. Dari gambar di bawah ini, warna merah menunjukkan sebaran vegetasi mangrove. Jelas terlihat bahwa ekosistem mangrove di wilayah Kota Surabaya tersebar di 3 lokasi dengan karakteristik berbeda, lokasi tersebut adalah di tepi pantai, sepanjang dan muara aliran sungai serta di sekitar tambak.

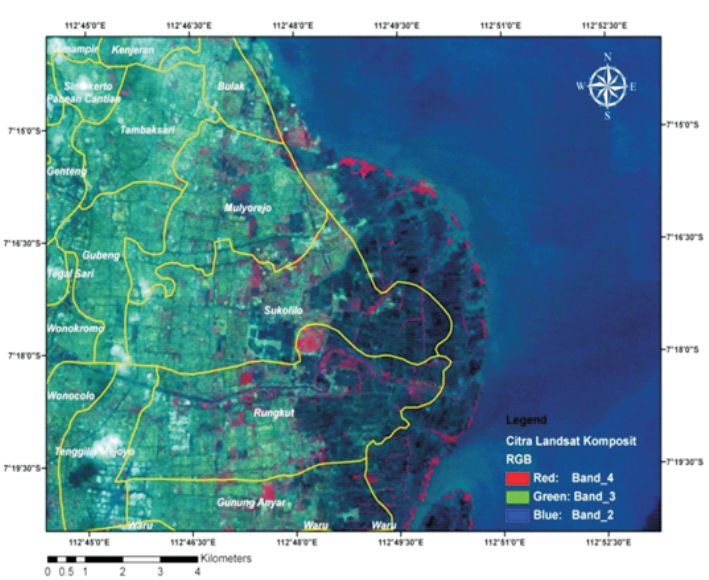

Gambar 1. Distribusi Ekosistem Mangrove di Surabaya Berdasarkan Citra Landsat TM-5 2009

Kawasan pantai selatan dan timur Surabaya merupakan daerah pesisir yang memiliki topografi yang datar sehingga air pasang laut dapat masuk beberapa kilometer ke arah daratan. Pada saat surut, akan terhampar pantai lumpur dengan kedalaman lebih dari $90 \mathrm{~cm}$. Kawasan itu menjadi sangat ideal, menjadi habitat pertumbuhan mangrove, karena selain air laut melimpah, ada air tawar dari empat sungai besar yang bermuara di lokasi tersebut, yakni Kali Wonokromo, Kali Wonorejo, Kali Keputih, dan Kali Dadapan. Distribusi ekosistem mangrove di kawasan Kota Surabaya disajikan pada gambar berikut ini :

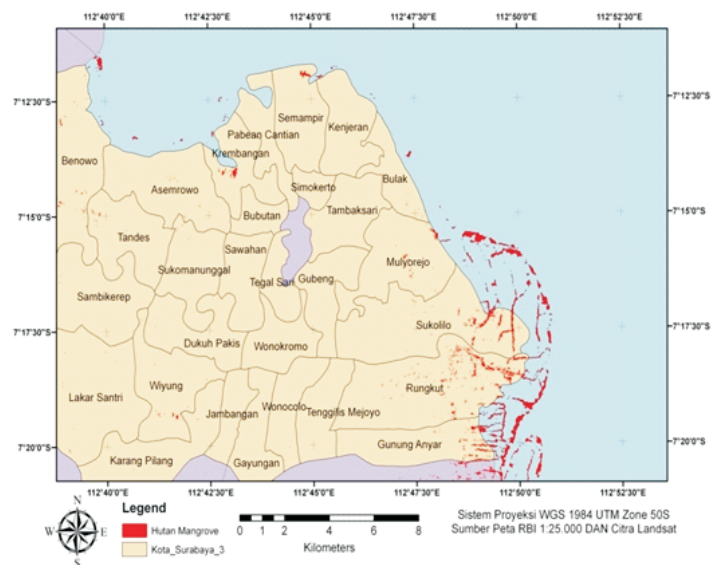

Gambar 2. Peta Sebaran Mangrove di Kota Surabaya Tahun 2009 
Tabel 1. Luas Ekosistem Mangrove di Wilayah Kota Surabaya Menurut Citra Landsat TM-5Tahun 2009

\begin{tabular}{|c|c|c|c|c|c|c|}
\hline \multirow{2}{*}{$\begin{array}{c}\text { Nama } \\
\text { Kecamatan }\end{array}$} & \multicolumn{5}{|c|}{ Klasifikasi Kerapatan (Ha) } & \multirow{2}{*}{ Grand Total } \\
\hline & Sangat Jarang & Jarang & Sedang & Rapat & Sangat Rapat & \\
\hline Asemrowo & 2.01 & 1.12 & 0.12 & & & 3.25 \\
\hline Benowo & 7.43 & 5.87 & 1.47 & 0.09 & & 14.86 \\
\hline Bulak & 0.98 & 1.90 & & & & 2.88 \\
\hline Dukuh Pakis & 0.12 & & & & & 0.12 \\
\hline Gunung Anyar & 8.91 & 7.86 & 3.81 & 0.44 & & 21.02 \\
\hline Gununganyar & 30.16 & 33.21 & 26.26 & 6.86 & & 96.49 \\
\hline Karangpilang & 0.51 & 0.15 & & & & 0.66 \\
\hline Kenjeran & 2.01 & 0.26 & & & & 2.27 \\
\hline Krembangan & 0.58 & 0.64 & 3.82 & 3.01 & & 8.05 \\
\hline Lakar Santri & 0.78 & 0.54 & & & 0.06 & 1.38 \\
\hline Mulyorejo & 8.38 & 5.41 & 8.24 & 7.52 & 0.44 & 29.99 \\
\hline Rungkut & 31.71 & 22.64 & 8.53 & 0.90 & & 63.78 \\
\hline Sambikerep & 0.20 & & & & & 0.20 \\
\hline Semampir & 4.70 & 3.22 & & & & 7.92 \\
\hline Sukolilo & 42.54 & 40.13 & 26.41 & 10.91 & & 119.99 \\
\hline Sukomanunggal & 0.14 & 0.09 & & & & 0.44 \\
\hline Tandes & 1.20 & 0.30 & 0.09 & & & 1.59 \\
\hline Wiyung & 0.53 & 1.68 & 0.95 & & & 3.16 \\
\hline Wonocolo & 0.06 & & & & & 0.06 \\
\hline Wonokromo & 0.09 & & & & & 0.09 \\
\hline Grand Total & 143.06 & 125.00 & 79.91 & 29.73 & 0.50 & 378.19 \\
\hline
\end{tabular}

Berdasarkan tabel diatas, terlihat bahwa luas total ekosistem hutan mangrove di wilayah Kota Surabaya pada tahun 2009 adalah 378,19 Ha. Daerah dengan luas hutan mangrove tertinggi adalah Sukolilo (119,99 Ha), Gununganyar (96,49 Ha) dan Rungkut $(63,78 \mathrm{Ha})$. Akan tetapi, berdasarkan klasifikasi berdasarkan indeks NDVI terlihat bahwa sebagian besar hutan mangrove di Kota Surabaya memiliki kerapatan rendah (jarang atau sangat jarang) dengan prosentase $33.05 \%$ dan $37.83 \%$. Sedangkan hutan mangrove dengan kerapatan tinggi, hanya memiliki prosentase sebesar $7.86 \%$ (rapat) dan $0.13 \%$ (sangat rapat). Prosentase luasan hutan mangrove berdasarkan tingkat kerapatan disajikan pada grafik dibawah ini.

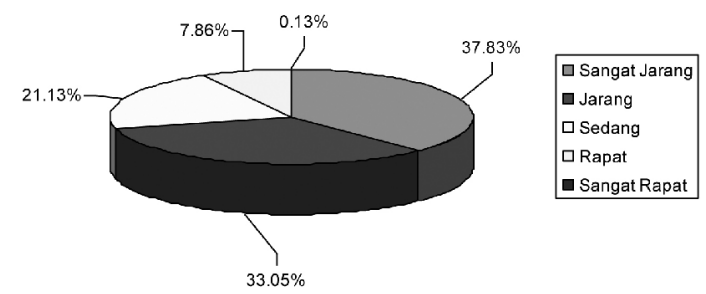

Gambar 3. Prosentase Luas Hutan Mangrove di Kota Surabaya Berdasarkan Tingkat Kerapatan
Dari data-data tersebut, dapat dikatakan bahwa secara umum kondisi mangrove di Kota Surabaya sudah mengkhawatirkan. Menurut beberapa penelusuran data sekunder, kerusakan ekosistem mangrove di Surabaya banyak disebabkan oleh perubahan peruntukan lahan (land use) untuk dijadikan lahan tambak (fish ponds) dan perumahan (housing). Untuk mencegah agar kerusakan terus terjadi, maka telah dilakukan beberapa upaya konservasi, seperti misalnya di muara Wonokromo dan muara kali Wonorejo.

Upaya-upaya rehabilitasi hutan dengan menanam mangrove harus memperhatikan dua hal penting. Pertama, melibatkan masyarakat pemilik tambak dan warga nelayan di kawasan muara Wonokromo dan muara Kali Wonorejo. Karena mereka setiap hari berinteraksi dengan mangrove, keterlibatan mereka dalam program rehabilitasi tersebut akan mendorong mereka melakukan pemeliharaan dan pengawasan. Kedua, pemilihan lokasi yang aman dari gangguan. Lokasi yang akan direhabilitasi haruslah mudah dijangkau/dikunjungi untuk mempermudah pengawasan dan perawatan. Selama ini, rehabilitasi mangrove di kawasan ini dilakukan secara memanjang menyusuri garis pantai. Meskipun menjangkau sepanjang pantai, bakal mangrove yang tumbuh rawan rusak karena diterjang 
ombak pasang air laut. Akan lebih efektif apabila rehabilitasi berupa petak-petak seperti tambak yang ada di belakang garis pantai. Meskipun tidak semua garis pantai terjangkau, kawasan rehabilitasi yang terpusat akan mempermudah perawatan dan memperkecil kegagalan penanaman karena lokasi terlindung dari air pasang (Noor dan Suryadiputra, 2006).

\section{Kondisi Ekosistem Mangrove Sidoarjo}

Hutan mangrove di Kabupaten Sidoarjo banyak tersebar di kawasan delta, muara sungai, pesisir pantai berlumpur dan sebagai tumbuhan yang ditanam di areal tambak. Berdasarkan hasil pengamatan dari citra satelit, mangrove banyak ditemukan di wilayah Sedati, Buduran, Sidoarjo, Candi, Porong dan Jabon. Distribusi hutan mangrove di Kabupaten Sidoarjo disajikan pada Gambar berikut ini :

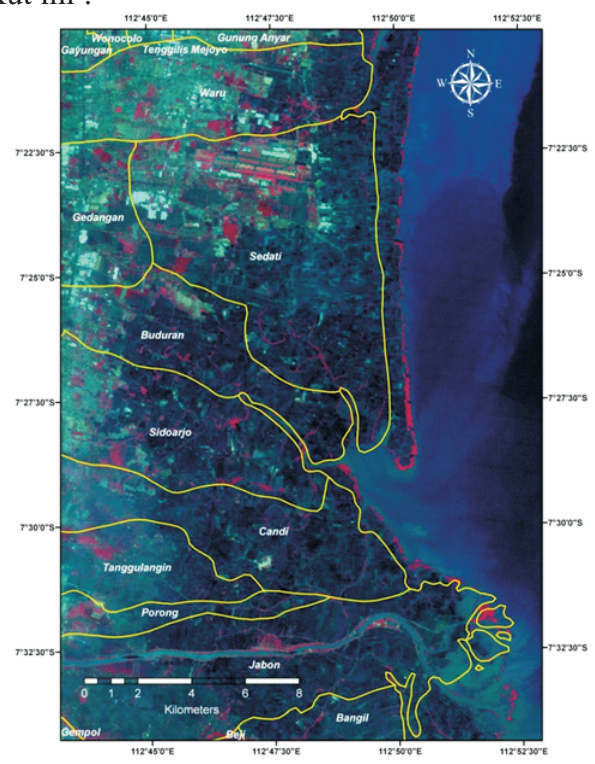

Gambar 4. Sebaran Ekosistem Mangrove di Sidoarjo Berdasarkan Citra Landsat TM-5 2009

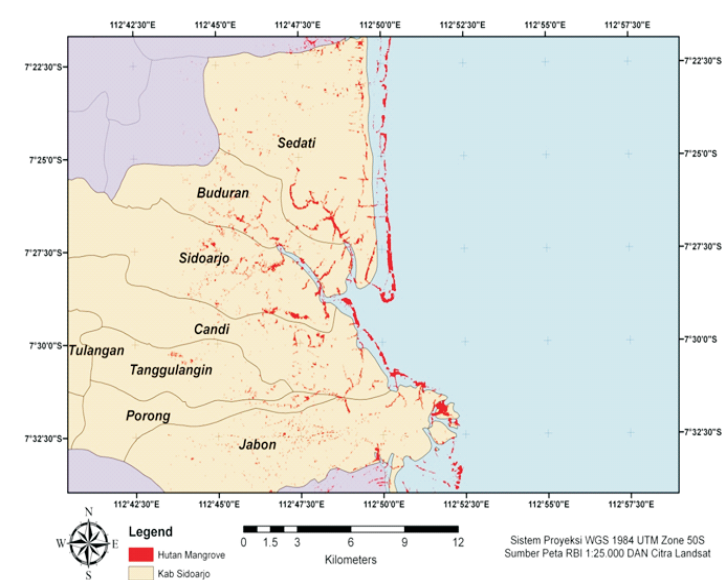

Gambar 5. Peta Sebaran Mangrove di Sidoarjo Tahun 2009

Menurut hasil analisa citra Landsat yang kemudian dilanjutkan dengan klasifikasi tingkat kerapatan vegetasi, maka dapat diketahui bahwa luas total hutan mangrove di Kab.Sidoarjo adalah 1.236, 42 Ha. Jenis mangrove yang mendominasi adalah Avicennia sp diikuti jenis Bruguiera sp, Rhizophora stylosa dan Sonneratia alba. Secara umum, terlihat bahwa prosentase antara hutan dengan kondisi rusak (kerapatan jarang dan sangat jarang) dengan kondisi hutan mangrove yang masih baik (kerapatan sedang sampai dengan sangat tinggi) cukup jauh berbeda. Akan tetapi apabila dilihat dari luasanya, hal ini dinilai lebih baik daripada kondisi di Surabaya. Luas hutan mangrove yang rusak di Kab.Sidoarjo mencapai 884,06 Ha, sedangkan hutan mangrove dengan kondisi baik mencapai luas kurang lebih 356,36 Ha. Prosentase hutan mangrove di kawasan pesisir Kab.Sidoarjo berdasarkan klasifikasi kerapatannya dapat dilihat pada table grafik dibawah ini :

Tabel 2. Luas Ekosistem Mangrove di Wilayah Sidoarjo Menurut Citra Landsat TM-5

\begin{tabular}{ccrrrrr}
\hline \multirow{2}{*}{ Nama } & \multicolumn{7}{c}{ Klasifikasi Kerapatan (Ha) } & \multirow{2}{*}{ Grand Total } \\
\cline { 2 - 5 } Kecamatan & Sangat Jarang & Jarang & Sedang & Rapat & Sangat Rapat & \\
\hline Buduran & 48.95 & 28.53 & 14.09 & 0.91 & & 92.48 \\
Candi & 62.37 & 36.21 & 34.65 & 5.33 & 0.17 & 138.74 \\
Jabon & 131.37 & 86.22 & 55.81 & 29.31 & & 302.70 \\
Porong & 9.72 & 3.61 & 0.40 & 0.09 & & 13.81 \\
Sedati & 137.58 & 106.63 & 75.94 & 60.42 & 1.02 & 381.59 \\
Sidoarjo & 67.72 & 39.56 & 24.59 & 8.61 & 0.06 & 140.54 \\
Tanggulangin & 10.37 & 7.43 & 0.32 & & & 18.12 \\
Waru & 66.65 & 41.13 & 28.14 & 12.52 & & 148.44 \\
\hline Grand Total & 534.74 & 349.32 & 233.93 & 117.18 & 1.25 & 1236.42 \\
\hline
\end{tabular}




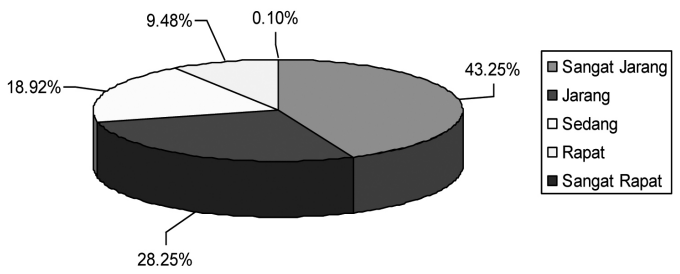

Gambar 6. Prosentase Luas Hutan Mangrove di Sidoarjo Berdasarkan Tingkat Kerapatan

Seperti halnya di wilayah Surabaya, ekosistem mangrove di Kab.Sidoarjo juga terancam kelestariannya. Akan tetapi, penyebab yang mengancam hutan mangrove di Sidoarjo berbeda dengan di Kota Surabaya. Di wilayah Sidoarjo, ancaman utama kerusakan ekosistem mangrove adalah penebangan liar dan kerusakan lingkungan akibat sampah domestik. Data Dinas Kelautan dan Perikanan Sidoarjo menyebutkan pelaku mengincar mangrove jenis api-api. Sebab, secara ekonomi jenis mangrove api-api memiliki harga jual tinggi. Tanaman mangrove jenis api-api diolah menjadi bahan makanan, kosmetik, dan obat-obatan sedangkan kayu tanaman mangrove diekspor ke Cina dan Korea. Selain itu, oleh masyarakat sekitar, kayu mangrove jenis api-api (Avicenia sp) digunakan untuk kayu bakar untuk rumah tangga maupun untuk industri bata dan genteng. Kayu dari jenis api-api terkenal karena mampu menghasilkan panas yang tinggi dan dapat dijadikan kayu arang berkualitas tinggi. Kerusakan hutan mangrove terparah di pesisir Jabon apabila dibandingkan dengan Waru, Sedati, Buduran, Sidoarjo, dan Candi.

\section{Kesimpulan}

Berdasarkan hasil analisa citra satelit Landsat TM-5 tahun 2009, luas hutan mangrove di wilayah Surabaya adalah sekitar 378.19 Ha. Sedangkan untuk wilayah Siodoarjo, luas hutan mangrove yang terdeteksi mencapai 1.236,42 Ha. Prosentase kawasan mangrove di Surabaya dengan kategori kerapatan jarang hingga sangat jarang adalah mencapai $>65 \%$. Prosentase ini tidak berbeda jauh dengan kawasan Siodoarjo pada kategori yang sama memiliki prosentase luas sebesar kurang lebih $73 \%$. Kerusakan ekosistem mangrove di dua kawasan tersebut lebih banyak diakibatkan oleh aktivitas manusia seperti penebangan liar, alih fungsi lahan mangrove menjadi tambak dan perumahan.

Untuk mencegah semakin tingginya tingkat kerusakan hutan mangrove baik di Surabaya maupun di Sidoarjo, maka upaya konservasi sangat dibutuhkan. Teknologi Sistem Informasi Geografis (SIG) dapat menjadi alat bantu (tools) untuk menunjang kegiatan konservasi. Fungsi yang dapat diperankan oleh teknologi ini selain sebagai penyaji data dan peta, juga dapat diaplikasikan untuk mendukung proses pengambilan keputusan (decission support systems) terutama dalam menentukan kesesuaian wilayah konservasi.

\section{Daftar Pustaka}

Bengen, D.G. 2000. Sinopsis Ekosistem dan Sumberdaya Alam Pesisir. Pusat Kajian Sumberdaya Pesisir dan Lautan-Institut Pertanian Bogor. Bogor, Indonesia.

Bengen, D.G. 2001. Pedoman Teknis Pengenalan dan Pengelolaan Ekosistem Mangrove. Pusat Kajian Sumberdaya Pesisir dan LautanInstitut Pertanian Bogor. Bogor, Indonesia.

Dahuri, M., J.Rais., S.P. Ginting., dan M.J. Sitepu. 1996. Pengelolaan Sumber Daya Wilayah Pesisir Secara Terpadu. PT. Pradnya Paramita. Jakarta, Indonesia.

Dahuri, R. 2003. Keanekaragaman Hayati Laut : Aset Pembangunan Berkelanjutan Indonesia. Jakarta : PT. Gramedia.

Hidayah, Z., dan Muhsoni, F. 2009. Pemetaan Ekosistem Mangrove dan Terumbu Karang di Wilayah Pesisir Madura. Laporan Penelitian. Dinas Perikanan dan Kelautan Jawa Timur (tidak dipublikasikan).

Hidayah, Z. 2009. Aplikasi SIG dan Penginderaan Jauh untuk Pemetaan Kondisi Kritis Hutan Mangrove di Kabupaten Pamekasan. Jurnal Kelautan Volume 2 No.2 Oktober 2009.

Levinton, M.J. 2005. Marine Biology : Introduction to Marine Ecology. Cambridge University Publisher. London.

Moloney, J.2008. Advance GIS and Coastal Mapping. Lecture Material. School of Earth and Environmental Sciences. James Cook University, Australia.

Noor. Y.R. Khazali, M. Suryadiputra.I.N.N. 2006. Panduan Pengenalan Mangrove di Indonesia. Ditjen PHKA/WI-IP. Bogor.

Nybakken, J.W. 1992. Biologi Laut Suatu Pendekatan Ekologis. Alih bahasa oleh M. Eidman., Koesoebiono., D.G. Bengen., M. Hutomo., S. Sukardjo. PT. Gramedia Pustaka Utama. Jakarta, Indonesia. 